\title{
Organic Amendment by Composting a Deficient Soil of the Niger Office Area in Mali
}

\author{
Mamadou BADIAGA ${ }^{1 *}$, Brahima B. TRAORE ${ }^{1}$, Boubacar TRAORE ${ }^{1}$, Hassana TOUNKARA $^{2}$, \\ Aimé A. SOMBORO ${ }^{2}$, Niaboula DEMBELE ${ }^{1}$, Nah TRAORE ${ }^{2}$, Drissa SAMAKE ${ }^{1}$. \\ ${ }^{I}$ Institute of Applied Sciences DER Applied Chemistry (CA-ISA), Badalabougou-Bamako Campus Avenue \\ Léopold Sédard SENGHOR BP E3206 \\ ${ }^{2}$ Faculty of Science and Technology (FST) DER Chemistry, Badalabougou -Bamako Campus
}

Avenue Léopold Sédard SENGHOR BP E3206

*Corresponding Authors: Mamadou BADIAGA, Institute of Applied Sciences DER Applied Chemistry (CA-ISA), Badalabougou-Bamako Campus Avenue Léopold Sédard SENGHOR BP E3206

\begin{abstract}
The structure and texture of the soil is an essential link for its stability and for the practice of good agriculture. However, with the intensification of cultivation techniques, the management of these parameters poses real problems. Soils may have a low water retention capacity or chronic impermeability. In the latter case, water stagnates and plants rot. Soils that also support intensive cultivation eventually become depleted of nutrients. Compost is an organic amendment that revitalizes deficient soils, hence the interest of composting. Composting improves the physical structure of the soil and its basic chemical properties. It is a biological process of conversion and valorization of organic matter. Composting makes the soil easier to work, more draining and better aerated. The Niger Office Area is an agro-pastoral region by excellency. However, the study area faces many soil-related problems: acidity, compaction, mineral element deficiency, silty-clay texture, and coarse structure. Therefore, a composting trial was carried out in this area.
\end{abstract}

The aim of this work is the development of a composting technique that can improve the physicochemical parameters of soils in the Niger Office Area and their productivity.

The composting period lasted for three months and finally a new compost was produced with standard physicochemical parameters. Thus, the $\mathrm{pH}$ measured on the finished compost varied between 8-9.The compost was spread over a 2.5-hectare trial field of two varieties of corn. The total amount of compost produced by biodegradation of fermentable material is 10 tons. Compost produced with an optimised nutrient-rich C/N ratio improved soil quality in a test pivot and increased crop yields.

Keywords: Soils analysis, Compaction, C/N Ratio, agricultural yield.

\section{INTRODUCTION}

The increasing infertility of agricultural soils in Mali led agricultural stakeholders to conduct further investigations to eradicate this scourge in order to ensure food self-sufficiency. Land degradation can be linked to irrational use of chemical inputs, the effects of environmental pollution, seed biodiversity or other factors [1]. This is how the idea of recycling organic materials of animal and vegetable origin came out to reinvigorate and revitalize farmlands. Hence the interest in composting with $100 \%$ natural raw materials [2].The analyzed soils in the Niger Office Area are faced with the major problem of compaction and acidity. The physicochemical analyzes concerned: particle size, $\mathrm{pH}$ and organic matter. The mineral particles of a soil are classified according to their size: this is the principle of particle size analysis. Agronomists in their activity have defined limits of particle size classes corresponding to different behaviors for each class: clays have an active role and silts are unstable [3]. The $\mathrm{pH}$ is an important physicochemical parameter in the dynamics of soil, it determines its degree of acidity or basicity. It is a real key in agronomy for the assimilation of nutrients by plants. The $\mathrm{pH}$ influences the three important components of soil fertility, namely nutrient biodiversity, biological activity and structural stability [4]. The $\mathrm{C} / \mathrm{N}$ ratio is an indicator to judge the degree of evolution of organic matter in the soil. This report is said to be high if it is around 15 to 25 , this corresponds to a poorly decomposed organic matter; $\mathrm{C} / \mathrm{N}$ between 8 and 12 corresponds to well 
decomposed organic matter; below $8 \mathrm{C} / \mathrm{N}$ indicates mineralized soils with low reserve of organic matter.

Assimilable phosphorus is essential for plants growth and development. The cation exchange capacity (CEC) of the soil represents the size of the reservoir to reversibly store certain cationic fertilizing elements $\left(\mathrm{K}^{+}, \mathrm{Na}^{+}, \mathrm{Mg}^{2+}, \mathrm{Ca}^{2+}\right)[5]$. The CEC value of a soil depends on not only the quantities of clay and organic matter it contains but also on the nature of the elements and the $\mathrm{pH}$ of the soil (IER SEP Laboratory analysis results canvas).

Previous analyses have shown a proven deficiency in major soil elements. Composting is being considered as an alternative for correcting soil deficiencies [6]. The aim of composting is to produce a low-cost natural organic amendment to enrich soils that are poor in essential nutrients $[\mathbf{7 , 8 ]}$. The composting technique consists in improving agricultural production and boosting organic agriculture. It is the best method for compensating for the process of advanced humus mineralization, a phenomenon that leads to soil denudation and degradation, especially in irrigated areas. Compost is a valuable product that overexploited soils constantly need. Compost is a fair return to nature from human waste or subsistence. Much more than a chemical fertilizer, compost has many positive effects on soil fertility and plant growth: it provides micronutrients for plant equilibrium, restores stable humus to the soil, improves the structure and balance of microorganisms, and regulates the soil water balance $[9,10]$.

Composting increases crop yield by adding more nutrients to the soil and significantly reduces the use of chemical inputs [11]. These inputs can be a source of nutrient depletion in arable soils. The uncontrolled use of these agricultural inputs can lead to environmental pollution. In this context, to be sustainable, agricultural production must develop approaches aimed at making better use of available resources, including restoring and maintaining soil fertility, which is one of the most limiting factors in agricultural production $[12,13,14]$.

Composts production is economically less expensive than that of chemical fertilizers. To rationalize green agriculture with a better yield, composting can be a vector of optimization for countries of the South like ours. The process consists in producing natural organic amendments from crop and livestock wastes at low cost to enrich agricultural fields. Enriched soils make it possible to improve agricultural production and boost traditional agriculture.

\section{MATERIAL AND MethodS}

\subsection{Material}

\subsubsection{Soil sampling:}

Soils were randomly sampled from different locations on the same Pivot in the Niger Office Area at Segou Region in Mali. They were sampled and divided into three separate lots (beginning, centre and end of Pivot) in numbered plastic bags and sent the same day to the Laboratory Soil-Water-Plants of the "Institutd' Economie Rurale" of Bamako for analysis.

\subsubsection{Composting process:}

Composting was carried out with the raw materials obtained from crop and livestock waste. In our case, we used manure, litter and crop residues (straw, processing waste on the farm). An automatic watering system fed the composting windrows. The turning of the heaps was done by mechanical and manual means. Composting depends on the nature of the materials to be composted and the equipment used. The material used is $100 \%$ natural and biodegradable.

\subsection{Methods:}

\subsubsection{Soils sampling:}

The soil samples were taken at a depth of $30 \mathrm{~cm}$ in the morning around 8 am and divided into three batches respectively. A required quantity of one kilogram was received for each sample [15]. The batches were numbered S1, S2 and S3 and then sent to the Soil-Water-Plants Laboratory of "Institutd" Economie Rurale" of Bamako for physicochemical analysis. The objective of sampling is to take a quantity of material whose volume is easily transportable and sufficiently representative for the analysis to demonstrate various characteristics. The sample is handled in such a way that its composition is not altered during transport and precautions are envisaged to avoid a change in composition caused by the temperature or storage method. 


\subsubsection{Windrow composting technique:}

Composting is a biodegradation process of $100 \%$ natural organic matter by microorganisms. This involves transforming biomass (organic waste of plant and animal origin) into a product with high humic value called "compost" or stabilized organic manure without damaging the environment. The process is simple and very easy to implement. It consists in developing green agriculture which will restore the nutrients missing from the soil. The technique consists in degrading under controlled conditions organic waste in the absence of oxygen then in the presence of oxygen, air and water (moisture). It results in the production of a more or less stable product used to improve soil quality(arable land). For good composting, it is recommended to mix the waste rationally to obtain a good balance of the carbon/nitrogen ratio $(\mathrm{C} / \mathrm{N})$, adequate moisture and good ventilation [16].

For this, we used the following proportion: two for carbon (2C) and one for nitrogen $(1 \mathrm{~N})$. Three windrows were designed at the beginning of the process with 1 meter wide, 35 meters long and 1.5 meter high each. Note that green and wet materials are loaded with nitrogen and dry ones are loaded with carbon. For windrows, the nitrogen layer is interposed between two carbon layers. The composting methods and the nature of the material vary widely. The windrows allow larger quantities of material to be composted. The sizes of the windrow depend on the size of the material used to turnaround the compost. Larger ones complicate ventilation. The three windrows were watered and then covered with plastic sheeting. A regular watering frequency of three times a week was adopted during the first two weeks of composting. The plastic covering kept the temperature around $55^{\circ} \mathrm{C}$ for two weeks. This practice destroys most pathogens and weed seeds [17]. A good turning of windrows ensures uniform mixing of the material they are made of. This reduces the risk of hot spots, subject to overheating or an accumulation of high moisture content materials that compromise microbial activity. The frequency of turning depends on the evolution of water content and temperature. The water content of the windrow usually decreases after turning, leaving room for air and oxygen spaces. However, the temperature will rise rapidly over the next few hours and then stabilize gradually. To maintain optimal microbial activity, ensure that the water content of the compost is also optimal. Since overturning tends to mechanically break up the soil particles, turning the compost too frequently can result in too fine particles. This reduces porosity and natural air movement in the windrows. Avoid returning them frequently as this can increase nitrogen losses. Compost needs time to mature and the degree of maturation corresponds to the degree of humification, or conversion of organic matter into stabilized humus which resists bacterial decomposition. For compost maturation, the size of the heap is less important than during the active phases. To ensure high-value composting, wooden stakes (beacons) must be inserted at both ends and in the center of the windrows. At maturity, the ends of the stakes buried in the heaps cool down and if they are hot the decomposition follows its biological process. The compost was analyzed at the Laboratory Soil-Water-Plants of the "Institutd' Economie Rurale" of Bamako.

\subsubsection{Development of Pivot test:}

The Pivot test is the experimental framework that served as a compost test on cultivated soils in the Niger Office Area. The physicochemical parameters of the obtained compost are compared with those of a liming amendment. Thus, the pivot is divided as follows:

- Portion 1: A 3-hectare unamended and unlimed control field (S1);

- Portion 2: A 2.5-hectare composted land (S2);

- Portion 3: A 2.5-hectare limed land (S3).

\section{RESULTS AND DISCUSSION}

\subsection{Soil analysis:}

The physicochemical analyzes of the three soil samples concerned $\mathrm{pH}$, specific conductivity, organic matter, nitrogen, assimilable phosphorus, exchangeable bases, cation exchange capacity, manganese content and texture.

Table1.Results of soil samples analyzes

\begin{tabular}{|l|l|l|l|l|l|l|l|l|l|l|l|l|l|l|}
\hline $\begin{array}{l}\text { Soil } \\
\text { Sampl } \\
\text { es }\end{array}$ & $\mathrm{pH}$ & $\begin{array}{l}\text { Specific Con } \\
\text { duc }\end{array}$ & $\begin{array}{l}\% \\
\mathrm{VS}\end{array}$ & $\begin{array}{l}\mathrm{NO} \\
\mathrm{T}\end{array}$ & $\begin{array}{l}\mathrm{P}_{2} \mathrm{O} \\
5\end{array}$ & $\begin{array}{l}\mathrm{CE} \\
\mathrm{P}\end{array}$ & $\begin{array}{l}\mathrm{Ca}^{2} \\
+\end{array}$ & $\begin{array}{l}\mathrm{Mg} \\
2+\end{array}$ & $\begin{array}{l}\mathrm{K}^{+} \\
\mathrm{meq}\end{array}$ & $\begin{array}{l}\mathrm{Na}^{+} \\
\mathrm{meq}\end{array}$ & $\begin{array}{l}\mathrm{Mn} \\
\mathrm{mp}\end{array}$ & $\begin{array}{l}\text { San } \\
\mathrm{d}\end{array}$ & $\begin{array}{l}\text { Sil } \\
\mathrm{t} \\
\%\end{array}$ & $\begin{array}{l}\mathrm{Cla} \\
\mathrm{y} \\
\%\end{array}$ \\
\hline
\end{tabular}




\begin{tabular}{|c|c|c|c|c|c|c|c|c|c|c|c|c|c|c|}
\hline & & & & & & $\begin{array}{l}/ \\
100 \\
g\end{array}$ & $\begin{array}{l}/ \\
100 \\
g\end{array}$ & $\begin{array}{l}/ \\
100 \\
g\end{array}$ & $\begin{array}{l}100 \\
\mathrm{~g}\end{array}$ & $\begin{array}{l}100 \\
\mathrm{~g}\end{array}$ & & & & \\
\hline $\mathrm{S} 1$ & $\begin{array}{l}5.6 \\
3\end{array}$ & 0.31 & $\begin{array}{l}0.2 \\
2\end{array}$ & $\begin{array}{l}0.0 \\
1\end{array}$ & $\begin{array}{l}16.9 \\
3\end{array}$ & 4.32 & 1.86 & 0.92 & 0.04 & - & $\begin{array}{l}2.8 \\
2\end{array}$ & 94 & 2 & 4 \\
\hline S2 & $\begin{array}{l}5.5 \\
2\end{array}$ & 0.49 & $\begin{array}{l}0.2 \\
9\end{array}$ & $\begin{array}{l}0.0 \\
1\end{array}$ & $\begin{array}{l}60.2 \\
8\end{array}$ & 4.51 & 1.96 & 0.98 & 0.07 & - & - & 27 & 72 & 1 \\
\hline S3 & $\begin{array}{l}5.5 \\
2\end{array}$ & 0.36 & $\begin{array}{l}0.5 \\
1\end{array}$ & $\begin{array}{l}0.0 \\
2\end{array}$ & 8.81 & 4.35 & 1.86 & 0.93 & 0.06 & - & - & 83 & 11 & 6 \\
\hline
\end{tabular}

Compared to the IER guide for interpreting test results, the soils are slightly acidic with a pH ranging from 5.52 to 5.63. These results are in line with those obtained during on-site sampling (pH between 5.5 and 6 ). The low specific conductivity value means that the soils are very slightly saline with a $\geq$ value of 0.25 . For organic matter, the $\mathrm{C} / \mathrm{N}$ ratio gives a relatively low quantity of nitrogen in the soils, which prevents the decomposition of carbon rate. The critical threshold for organic carbon is $0.6 \%$, a soil is said to be organic when $18 \%$ of carbon is present. The total nitrogen critical threshold is $1.2 \%$. The assimilable phosphorus critical threshold is $7 \mathrm{ppm}$. The analyzed soils are globally poor in phosphorus. CEC results in too low a presence, which requires the supply of trace elements in the soils. The results compared to the AFNOR standards show that the soils are predominantly sandy with easy cation exchange. $\mathrm{Ca}^{2+}$ ions largely dominate the exchange while alkaline ions remain relatively negligible. $\mathrm{Ca}^{2+}$ ions permissible threshold is close to $50 \%$ of CEC exchange and the critical threshold is $0.20 \mathrm{meq} / 100 \mathrm{~g}$ for $\mathrm{K}^{+}$ions. This creates competition between soil and plantation in a field due to the scarcity of nitrogen, which prevents the decomposition of the amount of carbon. Manganese content is very low in soils with a presence below the critical threshold (5 ppm). Manganese can have a limiting factor on plant growth in sufficient or excess quantities. It is used in nitrogen assimilation and plays a role similar to iron. When the $\mathrm{pH}$ is below 5.5, manganese is very soluble and symptoms of toxicity are likely to appear in some plants. The use of trace elements is essential to correct nutrient deficiencies.

\subsection{Compost analyzes:}

The composting process requires an optimal level of carbon, nitrogen, oxygen and water. A good mixture of $100 \%$ natural raw materials is used to make the compost with an optimal ratio of carbon and nitrogen. It is essential to create good air circulation to supply oxygen to the microbes that will be active in the compost. During the biodegradation of fermentable materials, heat, water, $\mathrm{CO}_{2}$ and ammonia $\left(\mathrm{NH}_{3}\right)$ are released into the air. Mixing raw materials in appropriate proportions results in a good moisture content and $\mathrm{C} / \mathrm{N}$ ratio leading to a mature compost.

N.B.: Do not add liquid materials such as fresh manure to the pre-compost, otherwise possible pathogens may be reintroduced into the formulation.

The formulated compost is of natural origin and is very rich in organic matter, nutrients (NPK) and trace elements (Mn, Fe, B, ...) which corroborates the results obtained by Bernal et al ., 1998 [18].

Table2. Natural compost analysis results

\begin{tabular}{|l|l|}
\hline Composition & Content \\
\hline $\mathrm{pH}$ & $8-9$ \\
\hline Organicmaterial & $30 \%$ \\
\hline $\mathrm{C} / \mathrm{N}$ & $8.25 \%$ \\
\hline $\mathrm{NOT}$ & $4 \%$ \\
\hline $\mathrm{P}_{2} \mathrm{O}_{5}$ & $3 \%$ \\
\hline Trace elements & $1 \%$ \\
\hline Humidity & $20 \%$ \\
\hline
\end{tabular}

In view of the results produced, the fresh formulated compost has an alkaline $\mathrm{pH}$ with a very rich quantity of organic matter that is well decomposed according to the $\mathrm{C} / \mathrm{N}$ ratio.

Carbon plays a very determining role in agricultural productivity. Carbon sequestration in the soil will increase its organic matter content (fertility, productivity increase and food security). Various experiments on carbon sequestration have been conducted around the world. A wide variety of longterm comparative studies show that organic and sustainable systems improve soil quality by increasing soil organic and carbon levels with increased microbiological activity[19]. The stock of 
organic carbon in natural soils has a dynamic balance between the input of plant debris and the loss due to its decomposition (mineralization). Nitrogen, which is very important in agricultural production, is present in different organic and inorganic forms $\left(\mathrm{N}_{2}, \mathrm{~N}_{2} \mathrm{O}, \mathrm{NO}_{3}^{-}, \mathrm{NO}_{2}^{-}, \mathrm{NH}_{3}, \mathrm{NH}_{4}^{+}\right)$in nutrient cycles [20]. Biological nitrogen fixation by certain plants such as legumes and the production of mineral fertilizers have made a decisive contribution to the development of agricultural production. Lack of nitrogen in the fields leads to the programmed death of the crop. Nitrogen is the ideal component of proteins and other types of bonds (peptidic, nucleic in DNA and RNA). Plants absorb nitrogen in mineral form (ammonium $\mathrm{NH}_{4}{ }^{+}$and especially nitrate $\mathrm{NO}_{3}{ }^{-}$). Therefore, organic nitrogen must be mineralized by soil microorganisms. Soil is an important reservoir of nitrogen for plant nutrition, hence its use in organic amendments to feed crops. The essential action of nitrogen as an amendment concerns the upper part of plants: stems, branches and leaves.

Ideally, the $\mathrm{C} / \mathrm{N}$ ratio should be in the range of $25 / 1$ to $30 / 1$, but this range may vary depending on the material and conditions. Compost contains essential micronutrients such as manganese, which is used in agriculture as a major contributor to various biological systems such as photosynthesis and respiration [21].

After three months of composting, the windrow size has decreased significantly. The appearance of mature compost is physically similar to soils with a dark coloration. The windrows matured with an alkaline $\mathrm{pH}$ between 8 and 9. The total amount of 10 tons of compost is spread over an area of 2.5 hectares, i.e. 4 tons per hectare.

\subsection{Effects of compost on agricultural soils:}

The produced compost is compared to lime to assess their respective effectiveness in soil. In both cases, they are spread on agricultural plots. Spreading is a technique of applying agricultural inputs to the soil to correct a deficiency or improve yields. To amend a soil, is to make it more suitable for the culture of plants. Naturally, some soils are more fertile than others because of their structure and nutrient richness. However, compost acts both as an organic amendment and as a basic fertilizer [22]. In agriculture, the need for an organic amendment depends on the physical nature of the soil. The better the soil is prepared, amended and enriched with compost, the more limited the use of chemical fertilizers. To determine the role of compost in the field, it is recommended to apply it to a freshly ploughed plot. In this study, an area of 2.5 hectares with a $\mathrm{pH}$ of 5.5 is amended by the freshly produced compost. After a 72-hour observation of the amended area and rain watering, the measured $\mathrm{pH}$ of the applied area is slightly basic $(\mathrm{pH}=8)$. A second ploughing of the amended area is necessary to homogenize the soil in order to make the topsoil uniform before seeding. Two maize varieties from the Bamako IER were sown on the 3 portions of the land.

Table3.Measured $p H$ values

\begin{tabular}{|c|c|c|c|}
\hline \multicolumn{4}{|c|}{ PH measurement in the 3 sown portions } \\
\hline & $\mathrm{pH}\left(1^{\text {st }}\right.$ month $)$ & $\mathrm{pH}\left(2^{\text {nd }}\right.$ month $)$ & $\mathrm{pH}\left(3^{\text {rd }}\right.$ month $)$ \\
\hline Compost & 8.0 & 7.5 & 7.0 \\
\hline Lime & 9.0 & 7.5 & 6.5 \\
\hline Control & 5.5 & 5.0 & 4.0 \\
\hline
\end{tabular}

The $\mathrm{pH}$ value in compost decreases gradually but very slightly in soils unlike that of lime which decreases rapidly. This decrease is explained by the degree of mineralization of the organic matter and the plant's need for nutrients. Soil organic matter is the main indicator of soil quality, both for agricultural functions (production and economy) and environmental functions (carbon sequestration and air quality). Organic matter is the main determining factor of all biological activities. The quantity of fauna, its diversity, activity and microorganisms are directly related to the presence of organic matter [10].

Composting has fundamentally changed soil texture:

- The percentage of sand decreased from $94 \%$ to $27 \%$; while the percentage of silt increased from $2 \%$ to $72 \%$; however, the percentage of clay decreased from $4 \%$ to $1 \%$.

- It should be pointed out that the sandy fraction has less favorable properties in terms of agronomic value (slump permeability and poor in nutrients). The silty fraction plays a major role in soil fertility as it has a high absorbency capacity and is rich in humus and nitrogenous nutrients. The clay fraction 
contains the finest elements, i.e. those with the largest specific surface area; like silt, it also plays a decisive role in the management of soil fertility and stability.

Composting has also improved the assimilable phosphorus content from 16.93 to $60.28 \mathrm{ppm}$. Furthermore, carbon levels increased from $0.22 \%$ in the control field to $0.29 \%$ in the composted plot.

In Burkina Faso, Sawadogo et al., showed that compost can be used to repair and restore degraded soils [23]. This work showed that some physicochemical parameters $(\mathrm{pH}$, total organic carbon, total nitrogen, available phosphorus) increased slightly in the amended parts compared to the control. Thus, this work corroborates the results we obtained.

\section{CONCLUSION}

The composting of the various organic materials lasted for 91 days, requiring a series of watering and turning of the piles as needed. This practice led to the production of a darkcolored, mature compost with a granular appearance and no foul odor .The nutritional value of the compost is quite different from that of the raw materials that make up the mixture. As water evaporates, carbon degrades and evaporates as $\mathrm{CO}_{2}$, the volume of the compost decreases and phosphorus and most other nutrients become more concentrated. Part of thenitrogen is lost during composting and another part is converted from readily available forms (nitrate nitrogen $\mathrm{NO}_{3}{ }^{-}$and ammonia nitrogen $\mathrm{NH}_{4}{ }^{+}$) to more stable organic forms that are slowly released to the crop. Its application on an experimental field showed a prolonged release of its nutritional constituents over the agricultural campaign. The observation was visible on the plantations with an efficient diffusion of nutrients throughout the crop. Compost is a bio fertilizer formulated to provide the nitrogen-phosphorus-potassium (NPK) requirements of plants, it leads to the limited use of chemical fertilizers. In short, composting is a means envisaged to correct deficiencies related to agricultural soils. In the long term, it helps to reinforce the soils' capacity to improve their agricultural productivity at a lower cost and in an easily achievable way. However, farmers don't know this composting technique which should beinstiled in average farmers. Nowadays, composting remains the main way to correct and conserve soils at an optimal level of productivity.

\section{REFERENCES}

[1] Organisation des Nations Unies pour l'alimentation et l'agriculture (FAO), Rome, 2011, La pratique de la gestion durable des terres.

[2] Raabe, R.D.2001. The rapid composting method. University of California, US, CooperativeExtension, Division of Agriculture and Natural Resources.

[3] Peigné, J., Vian' J.F., Cannavacciuolo' M., Bottollier' B.,Chaussod' R. 2009. Soil sampling based on field spatial variability of soil microbial indicators. European Journal of Soilbiology, 45: 488-495.

[4] Peigné J., Védie H., Demeusy J., Gerber M., Vian J.F., Gautronneau Y., Cannavaccuiolo M., Aveline A., Giteau L.L., Berry D., 2009. Techniques sans labour en agriculture biologique. Innovations Agronomiques 4 : 23-32.

[5] Ibrahim El Akram ZNAÏDI, Etude et évaluation du compostage de différents types de matières organiques et des effets des jus de composts biologiques sur les maladies des plantes, Master of Science DegreeMediterranianOrganic Agriculture, Octobre 2002.

[6] Houot S., Francou C., Vergé-Leviel C., Michelin J., Bourgeois S., Linères M., Morel P., Parnaudeau V., Le Bissonnais Y., Dignac M.-F., Dumat C., Cheiab A. et Poitrenaud M., 2003. Valeur agronomique et impacts environnementaux de composts d'origine urbaine: variation avec la nature du compost. Les Dossiers de l'environnement de l'INRA, 25:107- 125.

[7] Eriksen G., Coale F., Bollero G., 1999. Soil nitrogen Dynamics and maize production in municipal solid waste amended soil. Agron. J., 91:1009-1016.

[8] Koledzi K. E., Baba G., Tchangbedji G., Agbeko K., Matejka G., Feuillade G., Bowen J., 2011. Experimental study of urbans waste composting and evaluation of it's agricultural valorization in Lomé (Togo). Asian J. Appl. Sci., 4 (4):378-391.

[9] Francou C., 2003. Stabilisation de la matière organique au cours du compostage: influence de la nature du déchet et du procédé de compostage, recherche d'indicateurs pertinents. Thèse de l'Institut national Agronomique de Paris-Grignon, 288p. 
[10] OuténdéToundou, Evaluation des caractéristiques chimiques et agronomiques de cinq composts de déchets et étude de leurs effets sur les propriétés chimiques du sol, la physiologie et le rendement du maïs (Zeamays L. Var. Ikenne) et de la tomate (Lycopersicumesculentum L. Var. Tropimech) sous deux régimes hydriques au Togo, Thèse de doctorat en physiologie végétale, 8 Mars 2016.

[11] Mustin M., 1987. Le compost: gestion de la matière organique. Eds François Dubusc, 954p.

[12] Stroosnijder L. 1981. A soil Water balance strudy of the Malian Sahel. Agronomy Abstracts.

[13] Onken and Wendt C.W. 1989. Soil fertility management and water relationships. In ICRISAT. 1989. Soil, crop, and Water management systems for rainfed agriculture in the Soudano-Sahelian zone: proceedings of international workshop, 11-16, Janv. P. 99-116 ICRISAT Sahelian Centres, Niamey, Niger, Patancheru, AP.502324? India: ICRISAT.

[14] Doumbia, 1997. La fertilité des sols maraîchers dans la Ville de Bamako. Sotuba, 61p. Mémoire de fin d'études.

[15] Dale Cowan, Measure and Manage - Soil sampling procedures, Agri-Food Laboratories CCA.On. http://www.agtest.com/articles/soil_sample_proc.pdf et de sources diverses. Consulté le 04 Mars 2019 à 16 H30.

[16] Brinton., William F. (1995). The control of plant pathogenic fungi by use of compost teas. Biodynamics. Janury-February. P 12-15.

[17] Godden B. (1986). Etude du processus de compostage du fumier de bovin. Thèse de doctorat en Sciences Agronomiques, Université Libre de Bruxelles. Laboratoire de microbiologie, 136 pages.

[18] Bernal, M. P., Navarro, M. A., Sanchez-Monedero, M. A., Roig, A., Cegarra, J., 1998. Influence of sewage sludge compost stability and maturity on carbon and nitrogen mineralization in soil. Biochem. SoilBiol., 30 (3): 305-313.

[19] Organisation des Nations Unies pour l'alimentation et l'agriculture (FAO), Rome, 2002, La séquestration du carbone dans le sol pour une meilleure gestion des terres, Rapport sur les ressources en sols au monde, v. 96 ISSN1014-8531, 76 pages.

[20] Ernst Spiess, Volker Prasuhn et Werner Stauffer, Influence de la fumure organique et minérale sur le lessivage des éléments nutritifs, Recherche Agronomique Suisse 2 (9): 376-381, 2011.

[21] OHK, K. Manganese nutrition of cotton under two boron levels. II. Cristal Mn level. Agronomy Journal, Madison, v. 66, p. 572-575, 1974.

[22] Amir S., 2005. Contribution à la valorisation de boues de station d'épuration par compostage: Devenir des micropolluants métalliques et organiques et bilan humique du compost. Thèse de Doctorat de l'Institut National Polytechnique de Toulouse, 341p.

[23] Sawadogo H., Bock L., Lacroix D., Zombre N. P., 2008. Restauration des potentialités des sols dégradés à l'aide du Zaï et du compost dans le Yatenga (Burkina-Faso). BASE, 12 (3): 279- 290.

Citation: Mamadou BADIAGA, et.al., (2020). "Organic Amendment by Composting a Deficient Soil of the Niger Office Area in Mali", International Journal of Research Studies in Agricultural Sciences (IJRSAS), 6(7), pp. 1-7. DOI: http://dx.doi.org/10.20431/2454-6224.0607001

Copyright: (C) 2020Authors. This is an open-access article distributed under the terms of the Creative Commons Attribution License, which permits unrestricted use, distribution, and reproduction in any medium, provided the original author and source are credited. 